See discussions, stats, and author profiles for this publication at: https://www.researchgate.net/publication/333339535

Dealing with the profession of sociology: opportunities and problems at the interface between training and professional development

Article in International Review of Sociology · May 2019

DOl: 10.1080/03906701.2019.1672349

CITATION

1 author:

Manuel Fernández-Esquinas

Spanish National Research Council

101 PUBLICATIONS 538 CITATIONS

SEE PROFILE

Some of the authors of this publication are also working on these related projects:

Project Proyecto COARES View project

Project nuevas formas de relacion entre ciencia e industria View project
READS

116 
Accepted for publication in May 2019.

International Review of Sociology/Revue Internationale de Sociologie, Taylor \& Francis

\title{
DEALING WITH THE PROFESSION OF SOCIOLOGY: OPPORTUNITIES AND PROBLEMS AT THE INTERFACE BETWEEN TRAINING AND PROFESSIONAL DEVELOPMENT
}

\author{
Manuel Fernández-Esquinas \\ Instituto de Estudios Sociales Avanzados, CSIC \\ mfernandez@iesa.csic.es
}

\begin{abstract}
This article analyses and critically discusses the professional situation of sociologists in the system of professions. Some characteristics of the sociological profession are analysed against emerging challenges in the knowledge society. The first section portrays the current situation of sociology in real work contexts as a multisector profession in multidisciplinary settings. The second section analyses some drawbacks in the training and guidance of sociologists by providing significant examples. Spain is used as a strategic research site that exemplifies the existence of a robust academic community facing professional challenges. The third section outlines several strategies for collective action at the interface between the university and the professional domain in order to improve the participation of sociologists in the labour market.
\end{abstract}

Key words: professions, sociology, labour market, organisational fields, sociological practice, Spain.

\section{INTRODUCTION ${ }^{1}$}

This paper analyses several social dynamics about sociology's place in the system of professions and discusses strategies to strengthen the role of sociologists in the labour market. It begins with a discussion of some key issues of the situation of sociology at

This work has benefited from the comments of José Antonio Gómez Yáñez, Luís Navarro and José Beltrán, and from numerous conversations with Clara Guilló, Lucila Finkel, Màrius Domínguez and the rest of my colleagues on the executive committee of the Spanish Federation of Sociology (FES). 
the interface between academia and the profession, and deals with endeavours for improving collective action that are common in associations, professional orders and higher education institutions in the field of sociology. One part of the discussion is based on empirical analysis that shows common trends in the profession of sociology. I use some examples of Spanish sociology as a strategic research site that is informative for southern European countries and other contexts with different professional regimes. Another group of ideas stems from many meetings and conferences in the framework of sociology associations over several years, where discussions point repeatedly to the difficulties that sociology graduates face when forging a professional career outside academia.

The discussion about the profession of sociology is a classic topic of the discipline. After many years of debate about the nature of sociological knowledge for solving practical issues and the moral stances of sociologists on the different uses of the discipline $^{2}$, the discussion is now far more complex. Naïve visions about the role of sociology (and other social sciences) as a neutral applied enterprise that places the fruit of empirical analysis at the service of the public good are less common. Nevertheless, an annoying problem has persisted over the years: we produce thousands and thousands of graduates every year and these graduates need jobs. Sociology has been unable to provide a consistent path to professionalisation. Perhaps the only clear codified profession for sociologists is the academic. This observation does not conflict with data of extensive employment opportunities beyond academia and scattered over a variety of sectors and jobs.

However, despite the growing presence of sociology in universities and research centres and the expanding labour market for the social sciences during the late 20th century, we foresee important challenges. In some countries social science graduates are faced with substantial problems to find jobs ${ }^{3}$. Social sciences are evolving in a multiplicity of new

\footnotetext{
${ }^{2}$ Lazarsfeld et al. (1974) feature a compilation of the so-called engineering approach concerning technical answers to concrete questions in order to make suggestions, represented by the Bureau of Applied Research in Columbia. Examples of the enlightenment perspective oriented to producing knowledge to increase understanding of the social processes for a variety of publics, and not necessarily for clients, are Janowitz (1972) and Gans (1992). For a historical overview and detailed essays about the different uses of sociology, see, for instance, the compilation by Halliday and Janowitz (1992).

${ }^{3}$ As a reference for empirical information I use the articles in the special issue of the Spanish Journal of Sociology, dedicated to analysing the situation of Spanish sociology in academia and the profession from surveys and statistical sources (Fernández-Esquinas et. al. 2016). Other works dealing with the profession of sociology in Europe are Breger et.al (2016). Regarding the meetings of sociology association, I refer mainly to the conferences of national associations of ISA (the International Sociological Associations), and ESA (the European Sociological Associations). In the latest editions, the issue of the profession of sociology has emerged as a key challenge. See, for instance, https://www.isa-sociology.org/en/conferences/council-of-national-associations/taipei-2017
} 
fields and growing across disciplines that conflate in the labour market and other institutions when career prospects based on social knowledge are sought (Abbot, 2001). Students and new graduates alike have one question on their lips: 'Where can I go with a sociology degree?' Increasingly we must answer the same question for prospective students, families, employers, institutions, funders and users. Often we provide answers that are as naïve as the old visions of applied sociology such us 'sociology provides theory and findings for other scholarly enterprises and practitioners', or 'sociology is part of a larger social process of public discussion and is committed to the education of public opinion'. Although they are acceptable, implicitly these answers mean that we lose real jobs to other social science disciplines that are more active in strategies to position themselves in the labour market, leaving sociology graduates and postgraduates on their own to make a living from their degrees.

The paper aims to contribute to the discussion on strengthening the position of sociologists in the labour market within a context of uncertainty and risk. I purposely focus on the drawbacks and challenges of the current situation, and therefore my approach is necessarily incomplete, since I do not mention the wide range of job opportunities and professional development paths offered by sociology degrees. However, the article claims that negative views about the lack of job opportunities and ideological perspectives in favour of a specific mission for sociology are not empirically grounded in the diversity of work situations of sociologists and provide little help for professional development.

I address analytical concepts from the sociology of professions as tools that help define the current features of sociology in the labour market and interpret the social dynamics affecting it. The first section sets out current trends in sociology within the system of professions. The second section analyses the drawbacks of sociology relating to job opportunities. In the third section, I take a normative stance and propose several options that will capitalise on the strengths of the discipline, including job specification, professional image and identity, and the organisation of university studies.

\section{WHAT DOES A SOCIOLOGIST DO IN THE KNOWLEDGE SOCIETY?}

Nowadays, the work of sociologists corresponds to that of a knowledge worker in the so-called knowledge society and economy (Keinnman \& Vallas, 2001). Social sciences

\footnotetext{
${ }^{4}$ These quotations are real examples taken from meetings of the national associations of sociology. Own translation.
} 
are a fundamental ingredient of the capacity to act associated with knowledge as a major force for innovation and social change (Adolf \& Stehr, 2014). Social knowledge is a pillar of key policies, such as education, social services, $R \& D$, territorial planning and many others. It is also relevant for private actors that use it to foresee their activities and investments, ranging from the corporate image and strategies of firms and corporations to the day-to-day planning of SMEs and NGOs. Therefore, sociologists deal with specialised capacities and abilities related to organised social arrangements that use knowledge to ground courses of action in specific social structures. Sociological knowledge is not easily labelled for a specific social purpose or mission. It is not easily encapsulated in disciplinary practices. Rather, it is transferred to different work contexts by codified documents and practices embodied in real persons. It is used by different actors and for a wide range of interests no matter the substantive origin of knowledge and the explicit mission of sociologists that produced original research or interpretative frameworks.

The notion of profession is an essential tool for mapping a relational and systemic view of knowledge production and utilisation sensitive to societal and institutional contexts. Sociological perspectives on professions have developed amid conflict about whether a profession should be defined by a particular knowledge base linked to occupations, or as a particular type of institutional organisation giving practitioners control over access, training, credentials and other resources (Adams, 2015; Brock \& Saks, 2015; Sciully, 2005; Saks, 2010). Interestingly, although sociologists have developed insightful perspectives from the latter view of professions as a conflictual a social process of demarcation of boundaries (Collins, 1990; Muzio, et al., 2013; Evetts, J., 1998; Evetts, 2013; Abbott, 2005), we tend to conceptualise the sociological profession from the former view as linked to traits of disciplinary knowledge ${ }^{5}$.

Conceptually, we rate the knowledge base interpretation of the sociological profession because we tend to regard sociology from a substantive point of view and because we are organised in a non-corporate way. Problems arise when we feel that other social science professionals working in overlapping socio-economic spaces attempt to build boundaries. Sociologists interact, compete or cooperate with other social science colleagues as part of a system of professions (Abbott, 1988). This concept helps understand professions by examining the knowledge base and organisational forms, as

\footnotetext{
${ }^{5}$ See, for example, the compilation of analyses of European sociology by Koniordos and Kyrtsis (2014).
} 
well as the content of professional life, in the complex environment in which they interact and compete for areas of activity with outsiders and among themselves. Knowing how professions claim their jurisdictions in each environment is important; that is, the task, functions, jobs and types of resources they aim to control. To that end, each profession attempts to exert influence, gain prestige and legitimacy, create networks and, occasionally, impose power by blocking access to other professions.

A key issue in the system of professions is the distinction between regulated and nonregulated professions (Saks, 2012). In contrast to doctors, engineers and lawyers, among others, non-regulated professions lack essential components for establishing their jurisdiction: the absence of legal regulations on access to practice and the lack of jobs reserved for legally acknowledged professionals (Reed, 2012). Sociology is considered a non-regulated profession because, in most countries, it has no authoritative mandate over a particular set of problems, no discernible clientele, admission to its rank is a de facto credential determined by the labour market, and it is organised in an entirely decentralised manner (Halliday \& Janowitz, 1992). The relative position of a nonregulated profession in a given country, and therefore the opportunities to manage economic resources and jobs, is shaped by two contextual factors: state regulations and the capacity for collective action.

First, professional regimes formed by policies and regulations imposed by the state exert considerable influence in the professional labour market. In some countries, professional jurisdictions are more state-centred. The state's role is through a more topdown approach when defining the legal conditions for entering into the profession and the demarcation of jobs, especially in public services and economic activities subject to regulations (Neal \& Morgan, 2000). In these countries, regulation enactment is influenced by the prevalence of political orientations about professional sectors, but also by groups of professionals entrenched in key policy departments, unlike other countries where the professional labour market is mainly self-regulated ${ }^{6}$.

Second, corporate practices in the form of collective action are also influential for professions. They are aimed at providing prestige, media visibility and professional

\footnotetext{
${ }^{6}$ Portugal, Greece, Italy and Spain are examples of state-centred and regulated labour markets for professionals. For instance, psychologists, social workers and educational workers, among others, have become semi-regulated professions in these countries, along with the development of public services that provide jobs; this is not so for sociologists, economists, political scientists, market researchers and journalists. Examples of profession-centred and less regulated labour markets are the UK, the Netherlands and the Nordic countries (Brock \& Sacks, 2015; Lane et al., 2002; Evetts, 2000).
} 
services to members, and are sometimes enforced by social networking and informal closure to outsiders (Nordenflycht, 2010). In sum, the situation of sociology as a nonregulated profession in most of the world is highly dependent on the capacity of professional groups to self-organise and exert influence on the state and other private actors regarding legitimised access to activity sectors and codified jobs, on a par with other professional groups playing in the same field.

From this perspective emerge three important features of the current situation of a sociologist's work in the knowledge society. First, sociology is a multisectoral profession distributed over many fields of activity. Second, it is practiced around specialties, as opposed to general practice. And third, it is undertaken in multidisciplinary contexts. These three characteristics are analysed in the following sections.

\section{Sociology is a Multisectoral Profession}

Over the years, sociology graduates have moved into many sectors or practices, although the image of sociology professionals has been closely associated with universities and research. The profession has often been represented by the discerning intellectual or researcher with close ties to academia. Sociologists were largely concentrated in universities and research institutions linked to the academic world while the discipline was expanding and consolidating, at least in countries with affluent academic sectors in democratic regimes. In contrast with this image, over the years multiple profiles of sociologists have emerged in numerous places in the public and private sphere. Nowadays, most sociology graduates and postgraduates work in private firms, government sectors and certain NGOs.

The discipline's progressive expansion into the professional world has occurred in the absence of an effective jurisdiction on occupations and related resources (Vacarezza, 2007). Sociology is not attached to work sectors organised around university credentials. It is a multisectoral occupation which corresponds to the highly varied nature of the discipline. Sociological knowledge can be applied in myriad ways, which is consistent with the discipline's diversity of themes, work and relations with multiple institutional contexts. The occupation of sociologist is therefore closely linked to the way its boundaries are defined and governed within the system of social sciences professions customarily associated with a university degree (such as industrial psychology, market research, communication science, some branches of economics and 
education sciences, and other disciplines). In most countries, there is no legally defined area of activity and no organisational field with an exclusively manageable resource. Accordingly, there is an overlap determined by orientation and influence around areas of practice.

In sociology, as in any other discipline, jurisdiction depends on an organised strategy to gain legitimacy and competences around sectors of activity and professional networks. As a non-regulated profession, special significance is given to prestige and the image of the efficient performance of specific tasks in comparison with professionals from related disciplines. Depending on the strategies and capacities of the organisations associated with the discipline, sociology will be in a better or worse position in the system of professions of a given country. Influential aspects include the quality of university training, orientation of study programmes, research excellence, and the capacity and corporate strategy of professional orders and scientific societies to defend interests and provide social and cognitive resources for their practitioners. Moreover, in state-centred professional regimes, a major issue is the influence over public services and areas of practice regulated by the state. The sum of all these factors contributes to showcasing the work of sociologists, the image associated with the discipline and, in general, the degree of social legitimacy attained.

\section{Sociology is Practiced Around Specialties}

The high levels of complexity reached in many sectors of activity in contemporary societies require sociologists, and other social scientists, to specialise and combine abilities in order to analyse and manage social situations in specific areas of practice (for instance, in social services, education, health, transport, energy, city planning, market research, human resources management or the media). Sociologists wishing to become solvent in one of these fields, aside from mastering the fundamental knowledge and tools of the discipline, must familiarise themselves with the way of functioning of an area of social life. That is, they must at least be aware of the operating principles that govern the organisational field (DiMaggio and Powell, 1988) to which a sector of activity corresponds, including specific legislation, policies, special organisational arrangements and the way other professionals work. Sociological specialties that have greater professional influence are organised around a relevant sector of activity in economic or social life (such as education, social action and social planning). They are poised to transfer knowledge about the real functioning of an organisational field, from 
the policies and regulations that affect it to the management of its specialised organisations.

Each work sphere entered by sociologists deploys certain methodologies and know-how aimed at clients or specific users. For this reason, sociology requires numerous crosscutting capacities and skills so that knowledge can be transferred to a series of tasks. This calls for different working styles for each situation. Therefore, essentialist views of sociology associated with a specific mission of the discipline from the early years of graduate training do not fit well with the expected competences that must be applied to special courses of action. In the 21st-century system of professions, a degree in sociology is a credential that provides entry to occupational categories divided into different types of professional streams, involving specific arrays of knowledge and abilities in organisational settings.

\section{Sociology is Undertaken in Multidisciplinary Contexts}

Complex organisational fields generally demand various professional profiles, in contrast to the academic world that is usually divided into disciplines and specialties attached to a discipline. The socialisation of professionals is developed in the interplay between academic sites and diversified work contexts. On the one hand, scholarly life is organised around a set of social institutions that form the pillars of a discipline, namely, an acknowledged body of knowledge, an epistemic community, and a training and knowledge production system ${ }^{7}$. On the other hand, problem-solving in many sectors of activity is increasingly divided into inter-disciplinary practice because complexity calls for a variety of skills that are spread over several professional groups. Though sometimes in contradiction with the specialisation, this involves the need for social science professionals with a broad view of a field and who are able to foresee both the conditioning factors and the outcomes of actions. It also involves the need to communicate beyond the discipline. Professionals offering knowledge-intensive services require skills in order to present their work, whether to clients, users or sponsors, which are quite different from the practices in the traditional academic world (Gómez Yáñez, 2012).

\footnotetext{
${ }^{7}$ Indeed, new and multidisciplinary specialties in the social sciences (for instance, management and market research) often replicate the very institutions of preceding disciplines and end up functioning as such. This includes the creation of legally endorsed university degrees, a corpus of knowledge intended to be codified, specialised scientific journals, handbooks, and scientific and professional associations. See, for example, Abbott (2001) for the formation of new disciplines in the social sciences.
} 
As a result, sociologists are unlikely to work only with colleagues from the same discipline. They contribute their knowledge alongside professionals from the natural sciences, the technologies or from other social sciences. This working context raises expectations in relation to work performance. It implies that professionals are expected to have expert knowledge and take responsibility for their decisions. It also involves demands in terms of time management and the teamwork inherent in a complex setting. Professionals must therefore adapt their knowledge and skills to multidisciplinary working environments, presenting arguments and useful techniques aimed at providing results adapted to each situation. In addition, they need to make their knowledge understandable and adapted to the capacity to intervene in a given social reality.

Depending on how much sociology can offer for solving specific problems, sociologists will have fewer or more possibilities of work. Interactions with other professionals are particularly important, especially from the natural sciences and technologies (European Science Foundation, 2013), when sociologists and professionals from other social sciences are called in to participate in order to solve complex problems. The possibility of working across disciplines therefore depends on whether other professionals and decision-makers in the public or private sphere can understand and use sociologists' contributions. A specific strategy for transferring sociological knowledge to different application contexts is therefore required.

\section{SOME PROBLEMS IN RELATION TO THE LABOUR MARKET: THE CASE OF SPAIN}

According to the trends outlined above, the contrast with the situation of sociology as practiced in many systems of professions uncovers important weaknesses that act as barriers. In this section, I use examples from Spanish sociology similar to those from other countries, especially in Southern Europe and Latin America (Agodi et.al, 2015; Vacarezza, 2007).

The historical development of sociology in Spain has not facilitated the construction of a professional demarcation and set of specific workplaces. Interestingly, the development of Spanish sociology from the 1950s to the early 1970s occurred mainly in firms and some parts of public administration because, for many years, the dictatorship banned sociology as a university degree. The first cohort of sociology graduates dates from 1978. Therefore, many acknowledged sociologists from that time were professionals working for firms and public policies, who had studied in other countries. 
From the earliest days of the discipline, sociologists have always performed highly diverse applied works in market research, consultancy, advertising, communication, urban planning, rural development and political guidance (Torres-Albero \& FernándezEsquinas, 2018). As many moved to academia from the professional sphere, these activities were either carried out at university in the form of consultancy, or sociologists working in other environments would frequently come and go between the university and the profession. Nevertheless, from the 1990s onwards, sociology as a profession has depended significantly on the university and academic research. ${ }^{8}$ The new generations of sociologists have mainly identified with the working styles and intellectual dynamics that prevail at university.

A salient weakness is the scant tradition in job specifications and labour profiles. When positioning themselves in the labour market, sociologists have given little thought to the surrounding work environment. Notable exceptions can be found in sectors of practice close to research, such as public opinion polls, market research and applied research to social problems (Díaz-Catalán et al., 2016; Domínguez-Amorós \& Gómez-Yáñez, 2016). Nevertheless, numerous specialties firmly rooted in the academic sphere lack a minimal design to fit with a field of activity (Beltrán-Llavador, 2016). ${ }^{9}$ Training programmes adapted to tasks where the specific skills of sociologists would be acknowledged because of their systemic nature and the important presence of social dynamics have barely been considered in university curricula. Academic investment in sociology degrees oriented to numerous sectors of practice in industry, public administration and non-governmental organisations has been seriously neglected by Spanish academic institutions (Guilló, 2007). A broad range of sectors, including city planning, transport, energy, innovation, human resources, market research and communication consultancy have been occupied progressively by other disciplines with a more proactive professional strategy and greater capacity of adaptation in the public and private labour markets (Sigalat, 2016).

\footnotetext{
${ }^{8}$ This situation has changed dramatically in recent decades. This 'hybrid' combination of academic work and professional practice is less common in Spain and in many university systems where professional promotion in universities is based on research and academic performance, mainly publications, and not on professional practice (Torres-Albero \& Fernández-Esquinas, 2015).

9 An example can be found in the titles of the master's degrees organised by sociology departments and faculties. Generic titles for master's degrees around contemporary social problems and social transformations, identities and social inequalities have been common. Master's oriented to professional practice are usually limited to social services, education and gender. Very few master's in sociology are directed at sectors of professional practice around an organisational field that provides jobs. See, for example, Beltrán-Llavador (2016); Fernández-Esquinas et.al. (2016).
} 
A second set of weaknesses includes professional identity and public image. There are some important barriers to the professional self-projection of sociology graduates. Sociologists have few reference groups in relevant sectors of activity. Few examples of roles beyond university can be identified by sociology graduates when mapping their career or by employers when seeking profiles of sociologists. During the period of secondary socialisation at university (Blois, 2013), students are usually unable to link the specificities of sociological knowledge with real occupations. Though very broad and complex, sociological training is not identified with sectors of practice. Students and young graduates are unlikely to be capable of publicly explaining the essential traits of their future work and the employment opportunities within their reach. What is sociology for? What does a sociologist do? These recurring questions, voiced by sociology undergraduates and new graduates alike (Rubinigh \& Beltrán, 2010; BeltránLlavador, 2014), are not easily addressed in public. ${ }^{10}$

This leads to a new professional resocialisation when sociology graduates seek to join the labour market. When graduates have difficulties finding jobs associated with sociology, in the absence of visible routes that connect university with the labour market, many of them gravitate to sectors controlled by other disciplines, whose jurisdiction in the system of professions is better defined. Accordingly, professional identity usually dissolves either when graduates decide to study a higher degree connected to professional work or when they embark on a career in the business sector or in public administration. Sociology graduates that make a career in another disciplinary setting do not usually identify themselves as such because they use conceptual frameworks and work practices that are seldom linked to their training as sociologists (Díaz-Calatán et al., 2016). Finally, another aspect related to identity and public image is the identification of sociologists with the figure of the critical intellectual or the academic researcher working for academia and the media. Occasionally, linking sociologists to these professional images presents a barrier to recruitment in specific sectors of activity associated with practical skills (Eyal \& Bucholz, 2010).

\footnotetext{
${ }^{10}$ These questions are the norm amongst students faced with complex disciplines. However, university professors claim that these questions are asked more frequently in later stages when students compare sociology with other degrees. On the one hand, they consider sociology to be an academic discipline that is scientifically less legitimate than others (for example, chemistry, mathematics or neuroscience). On the other, demands for justification or the questioning of results occur more often than in other degrees (Lahire, 2006).
} 
A third group of weaknesses lies in certain characteristics of universities, both in terms of the profile of university professors and the organisation of degrees. The requirements of academic careers dissociate professors from the world of practice because of the importance of publications and academic research projects as criteria for promotion. In Spain, for younger generations of professors, it is increasingly difficult to find a profile of a lecturer in tenure track or a full professor who has had significant work experience outside academia. The figure of the part-time lecturer, initially designed in the university system so that students would have contact with the professional world, does not always solve the problem. In many cases, they are professors with an academic research profile and little professional experience, whose situation is precarious and who are hoping to carve out an academic career ${ }^{11}$. In other cases, they are professionals working outside university, but whose jobs do not allow them to acquire and develop skills specific to sociology. The problem worsens in university departments, where the position of part-time lecturer is used as a short-term solution to cover the lack of fulltime posts for academic profiles, or where the teaching load is assigned without due consideration of the competences and experience of the lecturers. The role model of academic sociologist transmitted by the university is thereby strengthened, and the possibilities of connecting students with the labour market are limited. In the mid- to short-term, this is particularly detrimental to upholding the legitimacy of sociology degrees as useful credentials to access the labour market.

These circumstances have been present in the Spanish university system since the 1990s. Recently, however, they have been aggravated by the effects of the transition to the European Higher Education Area. University reorganisation has led to the emergence of new degrees in related fields and occasionally to the reduced visibility of sociology in master's programmes ${ }^{12}$. This has resulted in greater competition among students when choosing their university degrees. It has also occasioned greater competition among degrees that lead to similar jobs. The tenuous connection to the labour market and hazy image of academic research places sociology at a disadvantage when decisions on degree course options are based on expectations of employability. As a result, widespread concern is beginning to emerge in sociology departments and

\footnotetext{
${ }^{11}$ This situation is specific to the academic labour market in Spain, although pressure to publish and undertake academic research, and difficulties combining professional practice with a successful academic career at university, are also present in other countries, including Italy, Portugal and France.

${ }^{12}$ A list of sociology degree courses at public universities in Spain, as well as the principal master's degrees associated with sociology, can be found in Beltrán-Llavador (2016).
} 
faculties about how to maintain student numbers, stem the flow of student dropouts, offer employability options, preserve teaching positions and resources, and uphold the legitimacy of sociology both as a degree and as an important subject for other degrees.

Finally, another source of weakness lies in the capacity for collective action by organisations within the discipline, including university advisory bodies, scientific associations and professional orders. In academia, diverse paradigms and schools of thought hinder the creation of quality standards that generate consensus, leading to a considerable divergence in the demands placed on graduates and in the recruitment procedures for teaching staff. Such diversity contributes to the fragmentation of work practices in terms of subjects, research skills and knowledge transfer. As for organisations that defend the discipline in professional or scientific fields, affiliation has always been low and highly fragmented, which has led to a dearth of resources and capacity to design strategies for collective action. Paradoxically, sociology as a profession and academic activity is distinguished by an absence of resources for collective action, institutional designs and organisational arrangements outside academia, despite effectively guarding its space at universities for some years ${ }^{13}$.

\section{STRATEGIES TO ENHANCE THE EMPLOYABILITY OF SOCIOLOGISTS}

This section contains a series of arguments for possible strategies based on disciplinary strengths for positioning sociology in the labour market. I purposely depart from normative assumptions about the diversity of careers for sociologists based on the applicability of sociological knowledge. I offer options for overcoming barriers associated with narrow views that portray sociologists mainly as academics or intellectuals. To that end, several competitive advantages can be optimised to improve professional development, while contributions that have always distinguished sociology in terms of values linked to social welfare and better organisation of society can be strengthened. In particular, consideration is given to the definition of sociologists' work, the reinforcement of their image and professional identity, and to the organisation of university education.

\section{Job Specification in Sociology}

An important issue is linking the discipline with work profiles. For this purpose, the tasks of the sociologist can be specified in connection with occupations that are strategic

\footnotetext{
${ }^{13}$ These trends can also be seen in Italy and other southern European countries. See, for instance, Agodi et al. (2015).
} 
for an area of activity. Job specification usually follows two parallel paths: defining the specificity of competences and skills in order to fulfil a related series of occupations; and identifying problems that are considered important in specific organisational fields. ${ }^{14}$

Sociology has several strengths that help identify professional profiles. Firstly, sociologists make use of competences to comprehensively capture and analyse complex situations. The variety of approaches and theoretical concepts provided by sociological training, along with highly diverse methodologies and research techniques, help divulge the range of causes behind a situation or the variety of effects that can result from courses of action, whether intended or unintended. Secondly, an important strength is the versatility to combine macro and micro levels of analysis. Transferred to the labour market, this means that, with their analytical tools and methodologies, sociologists can cover a range of situations from small groups to aggregated social structures. Both extremes can be connected in order to work in meso-level situations, which is where occupations are usually performed. For example, a specific skill is the capacity to handle interaction situations within working contexts, while taking into account the influence of the macrosocial environment.

This advantage is especially strong in sectors of a systemic nature because of the importance of both social structure and social action embodied in individual and collective agents. Social knowledge is vital for operations in numerous areas of businesses and government bodies. Some have been practically abandoned by sociology as fields for study and practice, for example, energy, transport infrastructure, innovation policies, safety and security, insurance and many industrial sectors. Moreover, the large organisations in each of these sectors also make use of systemic elements that require managing complexity, such as human resources, positioning strategy and corporate social responsibility. Sociologists can opt to work in these sectors when they are able to understand and manage their complex social dynamics.

The competences outlined here are also appropriate for taking advantage of the growing demand for social data in modern societies. Private and public institutions need data in order to base their decision-making processes on reliable information on the most varied

\footnotetext{
${ }^{14}$ Job specification is usually concerned with listing the incumbent's qualification, skills and abilities that are needed to discharge the job efficiently. In this study, we use the terms competences and skills reciprocally. A competence is usually considered a capacity to mobilise various cognitive resources to confront a type of situation (Goñi-Zabala, 2004). It refers to the capacity to transfer what has been learnt, to be an autonomous learner and to solve problems. It requires sets of specific skills that enable knowledge to be put into practice.
} 
aspects of social settings (Boudon, 2004). Demand for social information, particularly in recent years, has intensified and neither governments nor corporations are prepared to relinquish it (Pérez-Yruela, 2007). Big data also reveal a systemic nature because, aside from technical requirements, conceptual tools are required in order to furnish them with social meaning.

Connecting these strengths with the labour market calls for efforts to be made in job specification in the current system of professions. Firstly, this entails showcasing generalist competences that define the training and professional identity of the discipline, along with some specific skills. Sociologists could therefore be defined as specialists in specific workplaces, with due consideration given to the specific arrangements of these sectors. Secondly, the tools of sociology can be placed in a practical context. This is not just about providing research techniques, expert guidance or intervention designs, but about exemplifying how such tools are used in practice, which requires combining them with cross-cutting management, and organisational and communication skills to adapt knowledge to specific situations.

\section{Professional Identity and Image of Sociologists}

Professional identity is crucial to the jurisdiction of any profession, because of its effects on employment opportunities. How graduates view their work determines their future to a large degree. The perception of work opportunities influences specialisation and career paths. Beliefs about expectations as professionals shape efforts to gain skills, while conditioning future employers' image of sociologists as professionals. In short, professional identity is a basic component for linking the discipline to real work contexts.

This aspect also includes some strengths because the identity of sociology is well rooted in a series of elements that distinguish it from other disciplines. First, sociology has forged a model of interpreting human action that is different from the models of economics and psychology. It functions as a cognitive lens, a specific way of observing social reality that is effective when applied to socially situated actions (Portes, 2016). It is different from the cognitive lenses used by economists, based on utilitarian behaviour, and those used by psychologists, based on emotions and other individual traits applied to specific types of social reality when working in their respective professional jurisdictions. Second, sociologists share a set of analytical concepts framed in the theoretical traditions of sociology itself (Mouzelis, 1995). These concepts are 
generally used in day-to-day work, from the classical concepts of "social action", "class", "reference group", "socialisation", and so forth, to contemporary concepts such as "social capital", "embeddedness" and "boundary object", in addition to the numerous theoretically grounded concepts specific to specialties. These concepts enable us to approach social reality in a distinctive way, obtain and interpret data, and understand interrelations with other parts of reality. In fact, these catalogues of theoretically grounded concepts are the main tools used by sociologists in their day-to-day work rather than complete sociological theories ${ }^{15}$.

Third, sociology is characterised by a set of methodologies and analytical techniques that are peculiar to sociological expertise. The methodological pluralism combines statistics, survey techniques and various qualitative observations adapted to different kinds of social reality. From this perspective, any specialty of sociology can be considered an empirical project, namely, a task that requires systematic analysis of a body of evidence in order to produce knowledge and to take decisions based on accumulated knowledge. It also distinguishes sociology, for example, either from cultural studies, which are mainly based on an interpretative nature of social objects, or from the disciplines linked primarily to social intervention, such as social work or social education. An additional strength is that sociology is interested in raising and solving questions, such as power, influence and inequalities combined with cultural dimensions related to values, norms and cognitive repertoires, which other professions do not approach with the same analytical tools (Halliday \& Janowitz, 1992).

In order to optimise these strengths, the distinctive elements of sociology can be transmitted in an organised fashion so that graduates can be socialised in a professional identity that exploits potentialities and prevents barriers that might arise from the absence of a specific professional sector. On the one hand, it is important to begin defining this identity early on in degree studies. From the outset, future sociologists should have a correct understanding of the elements that define their competences and their possibilities of specialisation and career development; they should be able to give a clear and succinct explanation in public of the value of their competences and knowledge, in order to counterbalance the lack of awareness among the lay public. Moreover, they must prevent the profession of sociologist from being overly associated

\footnotetext{
${ }^{15}$ Some sociologists call for alternative ways of teaching sociological theory based on concepts and schemes that can be used in practical situations, in addition to historical accounts of the main theories (see, for instance, Meer \& Lamont, 2016).
} 
with a rather generalist and occasionally abstruse image with few possibilities of being put to practical use. On the other hand, in order to construct a professional identity, students and graduates should clearly identify the potential role of sociologists in the labour market. They should distinguish the specific features of roles performed in the domain of knowledge-intensive professions, such as those of applied researcher, consultant or activist, in relation to roles in academic work. In particular, the identification of research as a constitutive part of any sociology job should be nuanced according to different work contexts. The work of sociologists is based on conceptual rigour and empirical observations grounded in research methodologies. That said, in the professional world, jobs that entail carrying out original research are few and far between. Very few sociology graduates have the opportunity to access resources to perform state-of-the-art research. In fact, a significant number of sociologists work in consultancy, which involves seeking and analysing the knowledge available, and adapting it to a given situation. Many others are required to use management skills, which are similarly based on the adaptation of accumulated knowledge. To that end, in addition to research methodologies, sociologists need to know the basics of consultancy and management in the professional setting in which they will work, in combination with budget management, teamwork and communication tools.

This complex set of roles also calls for careful handling of the critical aspect usually associated with the figure of the sociologist. The work of sociologists commonly contains a critical component, either because it contradicts common sense, or because it reveals aspects of ideology and power as the constituent parts of any social reality. Questioning purely utilitarian thought or extreme individualism in places where these views prevail also has a controversial component. However, for the purpose of professional identity, these features of the sociological canon should be attuned to the world of practice. It is possible to identify a basis of common humanistic values in the sociological tradition, such as freedom and wellbeing (Giner, 2003), although it is difficult to identify sociology at the service of a political cause that defines the essence of the discipline. The capacities of sociology have always been applied to numerous goals, whether in government, business or the third sector, and they have embraced a plurality of ideological positions. Sociological analysis is a social action that is distinct from political action, and from economic action related to commercial applied research and consultancy, although it can be interlinked with both realms (Martinelli, 2008). 
Resolving these dilemmas in the domain of work is one of the basic issues in sociology when dealing with the system of social science professions.

\section{University Training and the Labour Market}

The university continues to be the main foundation of the cognitive and professional aspects of a discipline. In terms of the connection of university training with the work domain, some of sociology's fortes include a strong presence in the university system, decades of experience and a range of teaching staff. The research corpus and development of specialties are very rich and increasingly recognised at international level. However, integration into the system of professions involves the profile of the teaching staff, training in practical competences and certain aspects of curriculum organisation.

A fundamental question is the division of work of the different types of professors. At university, lecturers are increasingly required to produce original knowledge and reach numerous milestones in the form of assessments in order to advance their academic career. This trend results in a profile of teaching staff with considerable expertise in some of the academic specialties. The positive aspects mean that students can be properly introduced to core subjects relating to theory and methodology, and a connection can be established with state-of-the-art knowledge in the globalised world of research.

In this situation, external part-time lecturers take on a particularly important role for practical training. The role of lecturers with real experience in the labour market is a tool for introducing future graduates to the professional world. These lecturers provide role models that connect them to identifiable jobs or to situations in which sociology is used in applied contexts. It is essential to ensure a suitable design of lecturer profiles and the subjects they must teach in seamless connection with the specific knowledge and competences required in sectors of professional practice. Lecturers who can fulfil this function should be recruited to act as reference models and to transmit the specific nature of work done by sociologists beyond academia.

As regards teaching, efforts should be made to ensure that curricular design includes some studies that correspond to activities in working environments. The design of specialties should take into consideration areas where sociology is applied in defined 
organisational fields. It is also important to anticipate possible demands from professional sectors, thereby avoiding oversupply in some specialties. Now and then, some topics of sociology proliferate in the university system, while others with employment potential that could be classed with job specifications for sociologists are seldom promoted because of cultural bias. The risk of specialisations with employment potential being snapped up by other disciplines is a real challenge that should be considered.

In this sense, there are several possibilities that still leave much room for improvement. The first is an exploratory task by universities whereby they detect and showcase the wide range of employment opportunities for sociologists, based on profile definitions and job catalogues in which professional careers can be pursued. A second route that could link training and employment is to define the role of double degrees, so that a degree in sociology can be compatible with a field of practice (for instance, sociology and social work, sociology and organisation science, sociology and city planning, sociology and human resources management, sociology and energy systems, and many others). Moreover, master's degrees could be designed to accommodate the specific features of a sector of activity and its corresponding organisational field.

For sociology study programmes to be linked to the labour market requires a significant injection of contents that provide graduates with guidance on working in multidisciplinary and results-oriented contexts. That is, they should focus on transmitting the cross-cutting skills required to manage complexity in the labour market: communication, teamwork, management skills and technical tools for the social sciences. In particular, a fundamental question is how sociologists should interpret their findings and knowledge and how they should make themselves understood compared with other professionals.

\section{CONCLUSIONS}

Sociology as a knowledge profession is spread over many fields of activity; it is practiced around specialties and undertaken in multidisciplinary contexts. Sociology is a discipline with a particularly versatile range of analytical and methodological tools, and accumulated knowledge from numerous areas of reality that provide useful intellectual and social resources for the labour market. From a personal development perspective, it offers various alternatives and employment opportunities, and allows for a wide range of personal preferences to be accommodated. It is difficult to find another degree that 
offers a similar variety of possibilities. It also offers graduates flexibility and the capacity to adapt to changing environments throughout their working lives. Such versatility is highly valued in some workplaces, and, in some countries, this is reflected in high employment outcomes.

In contrast, in other countries, sociology is facing important dangers. It is no longer clear whether sociology has a secure niche as an academic profession in the university. Accountability practices are increasingly taking into account practical orientations and employability when distributing resources in universities. Students and families look for degrees that offer prospects of employment. Other social science professions overlap in the same areas of application of social knowledge. Frequently, they borrow concepts and methods from sociology or other social sciences, internalising them in their own frameworks and using them inside their professional demarcation in a corporate fashion. The way to face these challenges and emphasise the potential of sociology calls for a more conscious and systematic understanding of the functioning of social sciences within the complex system of professions. Nevertheless, in contrast to other nonregulated professions, we face important dilemmas when defining strategies and job profiling because very often these tasks do not fit with our background and professional values. Some important questions arise when foreseeing jobs for sociologists: should we go a step ahead and define job specifications, or at least job streams? Are we considering jobs in firms and administrations with real potential for career development? To be more specific, do we again dare to specify sociology jobs as human resources consultants, market professionals, industrial advisers and many others in the industrial sector? What about in public administrations, NGOs and local communities? None of these sectors are new to sociologists. We have seen many examples in the traditions of enlightenment and applied sociology. Indeed, sociology graduates follow some of the abovementioned work paths to make a living, depending on their contextual opportunities. But many other graduates are also forced to seek jobs where their competences are not acknowledged and be resocialised in other fields that offer career prospects. These risks increase when institutional sociology withdraws from labour market strategies, while the system of social science professions evolves in the opposite direction.

My conclusions contrast with essentialist visions of sociology aligned with certain missions. It is better to have sociologists working at a wide range of sites that use social 
knowledge for different purposes not only because they are well equipped with a set of analytical tools that provide guidance, but also because they are based on a model of human action that is better adapted to some situations of a systemic social nature: the model of human action embedded in social relations, values and social structure. From that point of view, employing sociologists in firms, corporations, the public sector and civic organisations in positions that help inform decisions and design institutions may be effective for incorporating such a model of human action into real work sites. It can provide rationality by identifying planned and unanticipated consequences produced by collective action and pay attention to groups that are affected negatively. In sum, it is better to have sociologists in all kinds of jobs grounded in social knowledge than to leave those jobs to other professionals with simpler interpretations of human action.

Several strategies based on disciplinary strengths are possible for positioning sociology in the labour market in order to compete in the system of professions and counterbalance the above trends. First, institutionalising roles in private industry and public administration following the previous examples of other social science disciplines. Second, reserving specific slots for sociology in primary and secondary education and in other university degrees, preceded by a strategy of public image and political influence. And third, specifying connections to a set of institutions for which graduates can feel an affinity, by incorporating their problems, concrete procedures and way of functioning into the sociology curriculum. The old linear model of science and innovation, which assumes that the fundamentals of sociological knowledge and research, taught and practiced with no clear links to contexts of practice, will somehow lead to real jobs usually produces scant results. It is rather the opposite. If we do not take a stance, we will lose jobs to other disciplines that are better organised.

\section{REFERENCES}

Abbott, A., 1988. The system of professions. An essay on the division of expert labor, Chicago: The University of Chicago Press.

Abbott, A., 2001. Chaos of disciplines, Chicago: The University of Chicago Press.

Abbott, A., 2005. Linked ecologies: states and universities as environments for professions. Sociological Theory, 23, 3, 245-274.

Adams, T., 2015. Sociology of professions: International divergencies and research directions. Work, Employment and Society, 29,1, 154-165. 
Adolf, M. and Stehr, N., 2014. Knowledge, London: Routledge.

Agodi, M.C., Annandale, E., Baptista, L. and Cipriani, R., 2015. Report on national sociological associations in Europe, European Societies, 17, 281-300.

Beltrán-Llavador, J., 2014. ¿Para qué sirve la sociología?, Revista Española de Sociología, 22, 127-134.

Beltrán-Llavador, J., 2016. El área de conocimiento de sociología en las universidades españolas. Locus institucional e identidad académica, Revista Española de Sociología, 25 (3 Supl.), 155-169.

Blois, J. P., 2013. Entre la autonomía y la heteronomía: socialización universitaria y prácticas profesionales de los sociólogos en la Argentina, Revista Mexicana de Ciencias Políticas y Sociales, 58, 209-232.

Boudon, P., 2004. La sociología que realmente importa, Papers, 72, 215-216. (Traslation into the Spanish from 'The sociology that really matters', European Academy of Sociology, 2001 Annual Lecture).

Breger, W., Spate, K. and Wisemann, P., Eds., 2016. Handbuch Sozialwissenchaftliche Berufsfelder. Modelle zur Unterstüzung beruflich er Orienterungsprozesse/ Handbook of Social Sciences and Career Options. Models for supporting vocational orientation and employment, Wiesbaden: Springer.

Brock, D. M. and Saks, M., 2015. Professions and organizations: A European perspective, European Management Journal, http://dx.doi.org/10.1016/j.emj.2015.11.003

Collins, R., 1990. Market closure and the conflict theory of the professions. In: M. Burrage and

R. Torstendahl, Eds., Professions in theory and history: Rethinking the study of the professions, London: Sage.

DiMaggio, P. and Powell, W., 1983. The iron cage revisited: Institutional isomorphism and collective rationality in organizational fields, American Sociological Review, 48, 148-149.

Díaz-Catalán, C., Luxán, A. and Navarrete, L., 2016. Los sociólogos ante el mercado de trabajo, Revista Española de Sociología, 25 (3 Supl.), 45-71.

Domínguez-Amorós, M. and Gómez-Yáñez, J. A., 2016). Formación y competencias en la profesión del sociólogo/a, Revista Española de Sociología, 25 (3 Supl.), 17-43.

European Science Foundation, 2013. 'The good, the bad and the ugly'. Understanding collaboration between the Social Sciences and the Life Sciences, Brussels: A ESF Strategic Workshop-ESF.

Evetts, J., 1998. Professional identity, diversity and segmentation: the case of engineering. In: V. Olgiati, L. Orzack, and M. Saks (Eds.), Professions, identity and order in comparative perspective, Onati: Onati International Institute for the Sociology of Law.

Evetts, J., 2000. Professions in European and UK markets: the European Professional Federation, International Journal of Sociology and Social Policy, 18, 395-415.

Evetts, J., 2013. Professionalism: value and ideology, Current Sociology, 61, 778-796.

Eyal, G. and Bucholz, L., 2010. From the sociology of intellectuals to the sociology of interventions, Annual Review of Sociology, 36, 117-137. 
Fernández-Esquinas, M., 2015. El Sistema Nacional de I+D: políticas públicas y dinámicas organizativas, in Torres-Albero, C., Ed., España 2015. Situación social, Madrid: Centro de Investigaciones Sociológicas.

Fernández-Esquinas, M., Beltrán-Llavador, J y Navarrete, L., 2016. Introduction to the Special Issue. The Task Ahead: A Diagnosis of Spanish Sociology between the Academy and the Profession, Revista Española de Sociología, 25 (3 Supl.), 213-224.

Fernández-Esquinas, M., Finkel, L., Domínguez-Amorós, M. and Gómez-Yáñez, J. A., 2016. Studying and Practicing Sociology in Spain. In: Breger, W. et, al., Eds.: op. cit.

Gans, H., 2004. Public sociology: public action not public policy, Footnotes, 8, 2-14.

Giner, S., Coord., 2003. Teoría sociológica moderna, Barcelona: Ariel.

Gómez-Yáñez, J. A., 2012. La sociología como profesión, Revista Española de Sociología, 18, $125-130$.

Goñi-Zabala, J. M., 2005. El Espacio Europeo de Educación Superior, un reto para la universidad. Barcelona: Octaedro / ICE Universidad de Barcelona.

Guilló, C., 2007. De la Sociología precaria y clandestina a la Sociología crítica y transformadora, Revista Española de Sociología, 7, 77-87.

Halliday, T. C. y Janowitz. M., Eds., 1992. The sociology and its publics. The forms and fates of sociology organization, Chicago: The University of Chicago Press.

Janowitz. M., 1972. Professionalization of sociology, American Journal of Sociology, 78, 105135.

Lahire, B., 2006. ¿Para qué sirve la sociología?, Buenos Aires: Siglo XXI.

Lane, C., Potton, M. and Littek, W., 2002. The Professions Between State And Market: A Cross-national Study Of Convergence And Divergence, European Societies, 4, 2, 235-260.

Lazarsfeld, P., Sewell, W. and Wilensky, H., Eds., 1974. The uses of Sociology, New York: Basic Books.

Keinmann, D.S. and Vallas, L., 2001. Science, capitalism, and the rise of the knowledge worker, Theory and Society, 30, 451-492.

Koniordos, S. and Kyrtsis, A-A., Eds., 2014. Routledge Handbook of European Sociology, London: Routledge.

Martinelli, A., 2008. Sociology in political practice and public discourse, Current Sociology, 56, 3, 361-370.

Meer, N. and Lamont, M.. 2016. Michelle Lamont: a portrait of a capacious sociologist, Sociology, 50, 1, 1012-1022.

Mouzelis, N., 1995. Sociological theory. What went wrong?, London: Routledge.

Muzio, D., Brock, D. and Suddaby, R., 2013. Professions and institutional change: towards an institutionalist sociology of the professions. Journal of Management Studies, 50, 5, 699-721.

Neal, M. and Morgan, J., 2000. The professionalization of everyone? A comparative study of the development of the professions in the United Kingdom and Germany, European Sociological Review, 16, 1, 9-26. 
Von Nordenflycht, A., 2010. What is a professional service firm? Toward a theory and taxonomy of knowledge-intensive firms, Academy of Management Review, 35, 1, 155-174.

Pérez-Yruela, M., 2007. El retorno de la sociología, Revista Española de Sociología, 7, 13-26.

Portes, A., 2016. Economic sociology: a systematic enquire, Princeton: Princeton University Press.

Reed, M. I., 2012. Masters of the Universe: power and elites in organization studies. Organization Studies, 33, 2, 203-221.

Rubinigh, L. and Beltrán, G., 2010. ¿Qué hacen los sociólogos?, Buenos Aires: Aurelia Rivera.

Saks, M., 2010. Analyzing the professions: the case for a neo-Weberian approach. Comparative Sociology, 9, 6, 887-915.

Saks, M., 2012. Defining a profession: the role of knowledge and expertise, Professions and Professionalism, 2, 1-10.

Sciulli, D., 2005. Continental sociology of professions today: conceptual contributions, Current Sociology, 53, 6, 915-942.

Sigalat, E., 2016. La situación de los sociólogos españoles en el sector privado: implicaciones para la práctica y el desarrollo profesional. Revista Española de Sociología, 25 (3 Supl), 95-114.

Torres-Alberto, C. and Fernández-Esquinas, M. (2018): 40 años de sociología en España: el papel de la práctica sociológica en una sociedad plural, in: Pendás, B., Ed., España constitucional (1978-2018). Trayectorias y perspectivas, Madrid: Centro de Estudios Políticos y Constitucionales.

Vacarezza, L. S., 2007. Heterogeneidad en la conformación de la profesión académica: una comparación entre químicos y sociólogos, REDES - Revista hispana para el análisis de las redes sociales, $13,26,17-49$.

\section{Notes on contributor}

Dr. Manuel Fernández-Esquinas is Research Scientist at the Institute for Advanced Social Studies (IESA), an official centre of the Spanish National Research Council (CSIC). His research interest lies in the intersection of the sociology of innovation and innovation policies, focusing mainly on the social conditions that influence knowledge transfer. Currently he is serving as President of the Spanish Sociological Federation (FES) and Coordinator of the Research Network "Southern European Societies" of the European Sociological Association. 